\title{
PERAMALAN TRANSAKSI PEMBAYARAN NON-TUNAI MENGGUNAKAN ARIMAX-ANN DENGAN KONFIGURASI KALENDER
}

\section{Forecasting Non-Cash Payment using Arimax-Ann with Calendar Configuration}

\author{
Muhammad Luthfi Setiarno Putera ${ }^{1}$ \\ ${ }^{1}$ Fakultas Syariah Institut Agama Islam Negeri Palangka Raya \\ Jalan G. Obos Komplek Islamic Center, Palangka Raya, 73112, Indonesia \\ e-mail:1*m.luthfi@iain-palangkaraya.ac.id \\ Corresponding author*
}

\begin{abstract}
Abstrak
Akses internet yang luas mendorong masifnya penggunaan sistem pembayaran non-tunai. Di Indonesia, berbagai aktivitas dan transaksi ekonomi seringkali dipengaruhi oleh pergerakan kalender, terutama kalender Hijriyah. Tujuan penelitian ini untuk memodelkan dan meramalkan total pembayaran non-tunai di Indonesia dengan menambahkan konfigurasi kalender sebagai variabel. Metode ARIMA, ARIMAX dan hybrid ARIMAX-ANN menjadi model yang akan dibandingkan akurasinya. Model terbaik untuk peramalan jumlah pembayaran non-tunai adalah ARIMAX-ANN dengan RMSE terkecil, yaitu Rp 20,9 triliun. Spesifikasi model terbaik tersebut adalah $\operatorname{ARIMAX}(2,1,1)$ yang dihibrida dengan ANN yang inputnya diseleksi melalui regresi stepwise. Selain memenuhi asumsi galat yang identik, independen, dan berdistribusi normal, ARIMAX-ANN juga mampu mengikuti dinamika dan tren dari pembayaran nontunai, khususnya pada bulan jatuhnya Idul Fitri dan periode akhir tahun.
\end{abstract}

Kata Kunci : $A N N$, ARIMAX, ARIMAX-ANN, konfigurasi kalender, pembayaran non-tunai

\begin{abstract}
Huge internet usage boosts transactions using non-cash payment. In Indonesia, lots of activities and transactions are influenced by calendar movement, particularly that of the Islamic calendar. This work is to obtain the model and to forecast total non-cash payment with calendar configuration as an exogenous variable. The methods being compared are ARIMA, ARIMAX, and hybrid ARIMAX-ANN. The best model to forecast a total of non-cash payment is ARIMAX-ANN due to the least RMSE, Rp 20,9 trillion. The specification of the best model is ARIMAX $(2,1,1)$ combined with ANN whose input is selected through stepwise regression. Besides satisfying residual assumption, ARIMAX-ANN is quite well in capturing the dynamics and trend of non-cash payment, particularly that in Ied-Fitr month and end of the year.
\end{abstract}

Keywords: Calendar configuration, ANN, ARIMAX, ARIMAX-ANN, non-cash payment 


\section{PENDAHULUAN}

Kemajuan teknologi saat ini ditandai dengan penggunaan dan akses internet yang masif. Mengacu pada Statistik Telekomunikasi Indonesia, jumlah pengguna internet makin besar dan mengalami kenaikan dari $17,1 \%$ pada 2014 menjadi 39,9\% pada 2018. Hal ini yang kemudian mendukung berkembangnya pola pembayaran dengan sistem non-tunai. Sistem pembayaran dikatakan sebagai non-tunai jika tidak terdapat uang riil dalam skema pembayaran [8]. Media pembayaran tersebut dapat berupa Alat Pembayaran Menggunakan Kartu (APMK), yang terdiri atas kartu Debet, kartu ATM dan kartu kredit, yang biasanya dikeluarkan oleh bank. Terdapat juga uang elektronik (e-money) yang belakangan makin digemari karena mudah, aman, dan praktis sebab dapat dilakukan hanya melalui gawai (gadget) [3]. Fenomena tersebut kemudian mengindikasikan penurunan peredaran uang tunai dalam beberapa tahun ke depan.

Maraknya penggunaan sistem non-tunai dapat terlihat dari nilai transaksi pembayaran dimana tiga instrumen, yaitu kartu Debet/ATM, kartu kredit, dan uang elektronik, masing-masing menunjukkan peningkatan selama 2014-2018 [2]. Hal ini mengindikasikan makin tingginya animo masyarakat dalam menggunakan skema pembayaran non-tunai. Selain itu, diperoleh bahwa kontribusi uang elektronik (UE) terhadap total transaksi meningkat secara kontinyu (tidak pernah menunjukkan tren penurunan). Bahkan, peningkatan paling pesat dicapai oleh UE dengan pertumbuhan transaksi yang melebihi 10 kali lipat hanya dalam kurun waktu 4 tahun dari 2014 hingga 2018 [2]. Oleh karena itu, diperlukan pendekatan peramalan yang tepat terhadap total transaksi pembayaran non-tunai di Indonesia.

Dalam berbagai aktivitas perekonomian di Indonesia, terdapat fenomena menarik bahwa transaksi perekonomian melonjak tajam menjelang hari besar keagamaan, terutama Hari Raya Idul Fitri [13]. Hal ini turut terjadi pada nilai transaksi pembayaran non-tunai, tidak hanya terjadi pada sistem tunai. Hal ini mengindikasikan bahwa transaksi pembayaran non-tunai tidak terlepas dari efek kalender. Dikemukakan bahwa model deret waktu yang mempertimbangkan efek dari variasi kalender akan menghasilkan ramalan yang lebih akurat [15]. Selain itu, pola konsumsi di negara dengan mayoritas penduduk beragama Islam seperti Indonesia terbukti dipengaruhi oleh pergerakan penanggalan qamariyah [18].

Model peramalan yang mempertimbangkan efek kalender salah satunya dapat dikaji menggunakan ARIMAX (Autoregressive Integrated Moving Average with Exogenous). Dalam [13], ARIMAX dapat meningkatkan akurasi peramalan regresi deret waktu maupun ARIMA. ARIMAX merupakan model deret waktu ARIMA yang dikembangkan dengan melibatkan variasi kalender sebagai variabel penjelas (independen) [1]. Akurasi peramalan dapat ditingkatkan dengan mengkombinasikan aspek linier dalam ARIMAX dan aspek non-linier. Dalam matematika, terdapat beberapa metode yang dapat digunakan untuk menangkap dinamika variabel yang tidak linier, salah satunya Artificial Neural Network (ANN) [4], [5]. Melalui kombinasi ARIMAX dan ANN sebagai model hybrid, disimpulkan bahwa ARIMAX-ANN mampu menghasilkan ramalan yang lebih akurat daripada ARIMAX dan ANN yang berdiri sendiri [9]. Selain itu, penelitian [17] menemukan bahwa ramalan ARIMAX-ANN mampu mengikuti tren dan fluktuasi data karena mampu mermperbaiki akurasi model linier dengan pendekatan peramalan non-linier.

Penelitian ini dilakukan untuk memodelkan dan meramalkan total pembayaran non-tunai dengan Alat Pembayaran Menggunakan Kartu (APMK) dan Uang Elektronik (UE) dengan konfigurasi variasi kalender. Dalam penelitian ini, model yang digunakan untuk proyeksi (forecast) total pembayaran non-tunai, yaitu ARIMA, ARIMAX, dan hybrid ARIMAX-ANN akan dibandingkan akurasinya. Untuk memperoleh ramalan ANN, dua pendekatan untuk menyeleksi jumlah variabel input turut dibandingkan, yaitu berdasarkan signifikansi lag residual Autocorrelation Function (ACF) dan regresi stepwise [14]. Di Indonesia, belum ditemukan penelitian serupa yang menggunakan stepwise untuk menyeleksi input. Komparasi dilakukan untuk mencari model ARIMAX-ANN dengan ramalan paling akurat. Hal ini mengingat karakteristik total pembayaran non-tunai yang diduga menghasilkan nilai pembayaran lebih tinggi pada hari besar keagamaan. Penelitian ini diharapkan dapat memberi masukan bagi pemerintah dan otoritas terkait berupa model ramalan peredaran uang, terutama yang menggunakan skema non-tunai.

\section{METODE PENELITIAN}

\subsection{Sumber Data dan Variabel Penelitian}

Data penelitian ini merupakan data sekunder yang dihimpun dari Bank Indonesia melalui laman https://www.bi.go.id/id/Default.aspx pada menu Statistik Sistem Pembayaran. Variabel dependen $\left(y_{t}\right)$ adalah total transaksi pembayaran non-tunai melalui APMK dan UE per bulan dimana $t$ sebagai notasi waktu. 
Rentang data dimulai dari Januari 2009 hingga Juni 2019. Total pengamatan pada penelitian ini sebanyak 126 bulan. Pada penelitian ini, variabel $y_{t}$ memiliki satuan triliun rupiah (Rp triliun).

Pada penelitian ini, juga dimasukkan variabel-variabel yang diduga mampu menjelaskan pola dan tren dari total pembayaran non-tunai dengan rincian sebagai berikut.

1. Variabel dummy untuk bulan terjadinya Idul Fitri

Variabel ini untuk merepresentasikan posisi jatuhnya Hari Idul Fitri pada bulan ke- $t$ dalam kalender Masehi. Secara matematis, dinotasikan dalam

$$
\begin{aligned}
& D_{t-2}=\left\{\begin{array}{l}
1, \text { bulan ke- }(t-2) \text { Idul Fitri ( } 2 \text { bulan sebelum Idul Fitri }) \\
0, \text { bulan lainnya }
\end{array}\right. \\
& D_{t-1}=\left\{\begin{array}{l}
1, \text { bulan ke- }(t-1) \text { Idul Fitri ( } 1 \text { bulan sebelum Idul Fitri) } \\
0, \text { bulan lainnya }
\end{array}\right. \\
& D_{t}=\left\{\begin{array}{l}
1, \text { bulan ke- } t \text { (bulan pada saat Idul Fitri) } \\
0, \text { bulan lainnya }
\end{array}\right. \\
& D_{t+1}=\left\{\begin{array}{l}
1, \text { bulan ke- }(t+1) \text { Idul Fitri }(1 \text { bulan setelah Idul Fitri) } \\
0, \text { bulan lainnya }
\end{array}\right.
\end{aligned}
$$

2. Variabel dummy untuk bulan dan minggu terjadinya Idul Fitri

Variabel ini dipertimbangkan mengacu pada [12] dimana permintaan dan transaksi tunai mencapai puncaknya pada bulan ke- $t$ Idul Fitri jika Idul Fitri jatuh pada minggu ke-2, 3, dan 4. Karakteristik tersebut diduga serupa dengan total pembayaran non-tunai. Untuk Idul Fitri yang jatuh pada minggu ke-1, maka kecenderungan puncak transaksi justru terjadi satu bulan sebelumnya.

$D_{i, t}=\left\{\begin{array}{l}1, \text { bulan ke- } t \text { (bulan pada saat Idul Fitri) pada minggu ke- } i \\ 0, \text { bulan lainnya }\end{array}\right.$

$D_{i, t-1}=\left\{\begin{array}{l}1, \text { bulan ke- }(t-1) \text { Idul Fitri pada minggu ke- } i \\ 0, \text { bulan lainnya }\end{array}\right.$

dengan $i=1,2,3,4$.

3. Variabel dummy bulanan

Variabel ini merepresentasikan bulan dalam 1 tahun kalender Masehi dimana $M_{1}, M_{2}, \ldots, M_{12}$ untuk bulan Januari, Februari hingga Desember.

4. Variabel tren

Variabel ini dilibatkan dengan pertimbangan bahwa terdapat peningkatan total transaksi pembayaran non-tunai dari tahun ke tahun. Secara matematis, dinotasikan menjadi $t=1,2,3, \ldots, 126$.

Seluruh variabel dummy dan tren berperan sebagai variabel independen $(X)$ yang bertujuan untuk menjelaskan keragaman pada total transaksi pembayaran non-tunai. Adanya variabel dummy diharapkan dapat mengidentifikasi efek variasi kalender pada total transaksi pembayaran non-tunai.

\subsection{Tahapan Penelitian}

Penelitian ini menggunakan metode yang populer untuk peramalan, yaitu ARIMA dan ARIMAX. Dimasukkan pula model ARIMAX-ANN sebagai model hybrid yang mengkombinasikan aspek linier dan non-linier. Penelitian ini menggunakan Minitab 17, SAS dan Microsoft Excel sebagai software utama untuk mengolah dan menganalisis data. Berikut ini merupakan langkah-langkah analisis data yang dilakukan.

1. Melakukan analisis deskriptif.

2. Membagi data dalam dua bagian, yaitu data training dan data testing. Periode data training dimulai dari Januari 2009 hingga Desember 2017, sementara data testing dimulai dari Januari 2018 hingga Juni 2019. Data training digunakan untuk membentuk model, sementara data testing digunakan untuk mengetahui akurasi peramalan dari model-model yang ditawarkan [10].

3. Memodelkan data training dengan ARIMA, ARIMAX dan ARIMAX-ANN.

4. Melakukan pemilihan model terbaik

Indikator untuk menentukan model terbaik adalah Root Mean Square Error (RMSE). Model dengan akurasi yang lebih baik umumnya memiliki RMSE yang lebih rendah [10]. 


\section{HASIL DAN PEMBAHASAN}

\subsection{Autoregressive Integrated Moving Average (ARIMA)}

Model ARIMA (Autoregressive Integrated Moving Average) adalah kombinasi model AR dengan orde $p$ dan MA dengan orde $q$ yang mengalami pembedaan (differencing) dengan orde $d$ untuk data deret waktu bukan musiman [11]. Model ARIMA reguler untuk variabel $y_{t}$ dinyatakan ke dalam persamaan (1),

$$
\phi_{p}(B)(1-B)^{d} y_{t}=\theta_{q}(B) \varepsilon_{t} .
$$

Pada beberapa kasus, aktivitas ekonomi, konsumsi listrik, dan jumlah wisatawan seringkali memiliki pola tertentu, yaitu meningkat atau menurun pada waktu-waktu tertentu [16]. Hal ini mengindikasikan terdapat pola musiman dalam data tersebut. Model ARIMA untuk pola musiman disebut juga SARIMA (Seasonal ARIMA) atau ARIMA dengan musiman. Secara matematis, ARIMA dengan musiman dinotasikan ke dalam persamaan (2)

$$
\phi_{p}(B) \Phi_{P}\left(B^{S}\right)(1-B)^{d}\left(1-B^{S}\right)^{D} y_{t}=\theta_{q}(B) \Theta_{Q}\left(B^{S}\right) \varepsilon_{t},
$$

dengan

$$
\begin{aligned}
& \phi_{p}(B)=1-\phi_{1} B-\phi_{2} B^{2}-\ldots-\phi_{p} B^{p} \\
& \Phi_{P}\left(B^{S}\right)=1-\Phi_{1} B^{S}-\Phi_{2} B^{2 S}-\ldots-\Phi_{P} B^{P S} \\
& \theta_{q}(B)=1-\theta_{1} B-\theta_{2} B^{2}-\ldots-\theta_{q} B^{q} \\
& \Theta_{Q}\left(B^{S}\right)=1-\Theta_{1} B^{S}-\Theta_{2} B^{2 S}-\ldots-\Theta_{Q} B^{Q S} .
\end{aligned}
$$

Pada persamaan (1) dan (2), $B$ adalah operator backshift, $S$ adalah periode musiman, $d$ dan $D$ adalah orde pembedaan reguler dan musiman, dan $\varepsilon_{t}$ adalah galat white-noise dengan mean 0 dan varians konstan pada waktu $t$. Salah satu teknik untuk mengetahui eksistensi pola musiman adalah melalui struktur otokorelasi pada plot ACF [6].

\subsection{ARIMA with Exogenous (ARIMAX)}

Model ARIMAX (ARIMA with Exogenous) adalah pengembangan ARIMA yang melibatkan variabel independen $(X)$ untuk memodelkan variabel dependen $Y$ [12]. Penelitian ini menawarkan dua opsi model ARIMAX. Model pertama adalah SARIMAX dengan dummy variasi kalender dan model kedua adalah ARIMAX dengan dummy variasi kalender dan tren deterministik yang diwakili oleh dummy bulanan dan tren tahun. Model ARIMAX pertama secara matematis ditunjukkan dalam persamaan (3),

$$
y_{t}=\beta_{0}+\sum_{i} \beta_{i} D_{t}+\sum_{i} \gamma_{i} D_{i, t}+\sum_{i} \varphi_{i} D_{i, t-1}+\frac{\theta_{q}(B) \Theta_{Q}\left(B^{S}\right)}{\phi_{p}(B) \Phi_{P}\left(B^{S}\right)(1-B)^{d}\left(1-B^{S}\right)^{D}} \varepsilon_{t} .
$$

Untuk model ARIMAX kedua, dapat direpresentasikan menjadi

$$
y_{t}=\delta_{1} t+\sum_{s} \beta_{s} M_{s, t}+\sum_{i} \gamma_{i} D_{i, t}+\sum_{i} \varphi_{i} D_{i, t-1}+\frac{\theta_{q}(B)}{\phi_{p}(B)(1-B)^{d}} \varepsilon_{t}
$$

dimana model kedua tidak lagi memiliki kemungkinan terpengaruh oleh efek musiman.

\subsection{ARIMAX-ANN}

Artificial Neural Network (ANN) merupakan metode yang dikembangkan dengan konsep mereplika jaringan syaraf biologis ke dalam model matematis [14]. Salah satu model ANN yang digunakan untuk peramalan adalah feed-forward neural network (FFNN). Dalam model ANN, terdapat 3 lapisan yang menyusun model, yaitu input layer, lapisan semu (hidden layer) dan output layer [7]. Selain itu, aspek yang dapat mempengaruhi kebaikan model ANN adalah jaringan struktur, algoritma pembelajaran, laju 
pembelajaran dan fungsi aktivasi. Persamaan (5) menunjukkan hubungan matematis antara input $y_{t-1}, y_{t-2}, \ldots, y_{t-p}$ dan output $y_{t}$ dalam model deret waktu ANN

$$
y_{t}=\alpha_{0}+\sum_{j=1}^{q} \alpha_{j} g\left(\beta_{0 j}+\sum_{i=1}^{p} \beta_{i j} y_{t-i}\right)+\varepsilon_{t}
$$

dimana $i=0,1,2, \ldots, p ; j=1,2, \ldots, q$. Simbol $\alpha_{j}$ dan $\beta_{i j}$ adalah parameter pembobot dengan $p$ dan $q$ masing merupakan banyak elemen (node) pada input layer dan banyak node pada hidden layer. Salah satu fungsi aktivasi yang lazim digunakan adalah logistic sigmoid. Fungsi ini direpresentasikan dalam persamaan (6),

$$
g(t)=\frac{1}{1+e^{-t}} .
$$

Jadi, melalui persamaan (6), hal ini membuktikan bahwa model ANN merupakan model non-linier.

Model ARIMAX-ANN merupakan model hybrid (penggabungan) antara ARIMAX sebagai model linier dan ANN sebagai model non-linier [7]. Konsep kerja model hybrid cukup sederhana dan ditunjukkan dalam persamaan (7)

$$
y_{t}=L_{t}+N_{t}+\varepsilon_{t} \text {, }
$$

dengan $L$ dan $N$ mewakili linier dan non-linier [5]. Estimasi $L_{t}$ diperoleh dari model ARIMAX yang selanjutnya akan diperoleh galat model ARIMAX $a_{t}$. Galat $a_{t}$ kemudian dimodelkan dengan ANN sehingga memperbaiki keterbatasan ARIMA dalam menangkap aspek non-linier. Hasil pemodelan tersebut diwakili dengan $N_{t}$, sehingga diperoleh model ramalan hybrid ARIMAX-ANN berikut.

$$
\hat{y}_{t}=\hat{L}_{t}+\hat{N}_{t}
$$

\subsection{Deskripsi Statistik}

Pola dan dinamika dari total pembayaran non-tunai dengan APMK dan UE disajikan pada Gambar 1 dengan garis putus-putus berwarna merah mewakili periode bulan jatuhnya Idul Fitri.

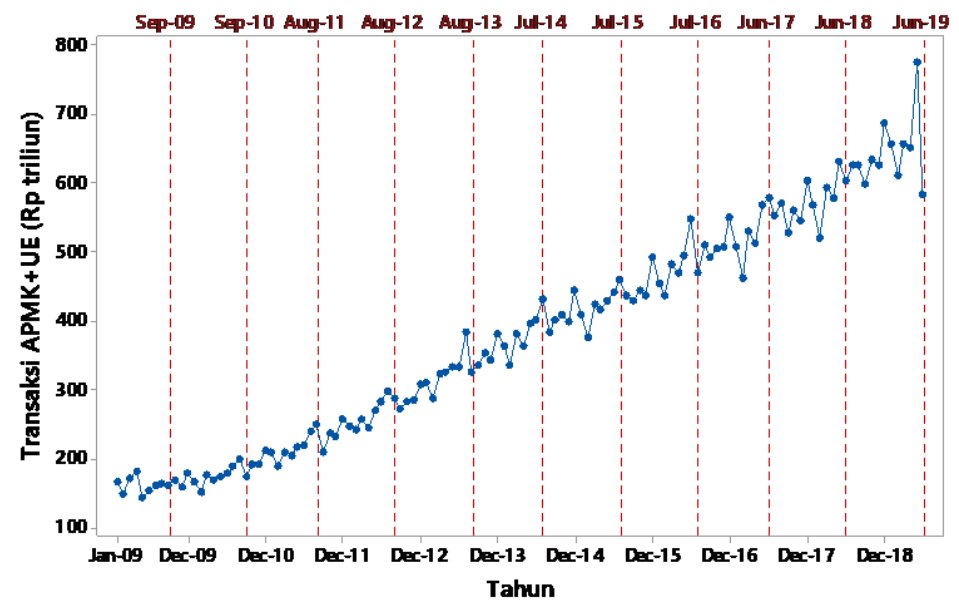

Gambar 1. Plot Deret Waktu untuk Total Pembayaran Non-tunai

Gambar 1 menunjukkan tren pembayaran non-tunai mengalami peningkatan pesat. Total pembayaran nontunai mengalami lonjakan yang tajam tepat pada bulan jatuhnya Hari Idul Fitri, antara lain pada tahun 2011 dan 2014. Pada tahun dimana Idul Fitri jatuh pada awal bulan, kenaikan signifikan pada pembayaran nontunai justru terjadi 1 bulan sebelumnya, antara lain pada tahun 2013 dan 2016. Selain 2 bulan tersebut, peningkatan pembayaran non-tunai juga terjadi pada 2 bulan sebelumnya, seperti pada tahun 2010 dan 2016. Selain pembayaran non-tunai diindikasikan dipengaruhi oleh variasi kalender, Gambar 1 juga memperlihatkan adanya peningkatan transaksi pada akhir tahun.

\subsection{Pemodelan Pembayaran Non-Tunai dengan ARIMA}

Gambar 2(a) menunjukkan bahwa data sudah stasioner dalam varians. Dengan kata lain, perubahan pada varians pembayaran non-tunai terjadi secara natural dimana fluktuasi nilai yang terjadi tidak begitu lebar. Sementara, Gambar 2(b) mengindikasikan bahwa data tidak stasioner dalam mean karena ACF yang turun lamban. Berdasarkan uji ADF, total pembayaran non-tunai terbukti tidak stasioner dalam mean. 
Artinya, hal ini mengindikasikan bahwa rata-rata total pembayaran non-tunai tidak konstan selama periode tertentu. Jika dihubungkan dengan bulan jatuhnya Idul Fitri dan periode lain yang bertepatan dengan libur panjang, maka hal ini dapat memicu meningkatnya aktivitas perekonomian dan berimplikasi pada signifikannya kenaikan total pembayaran non-tunai.

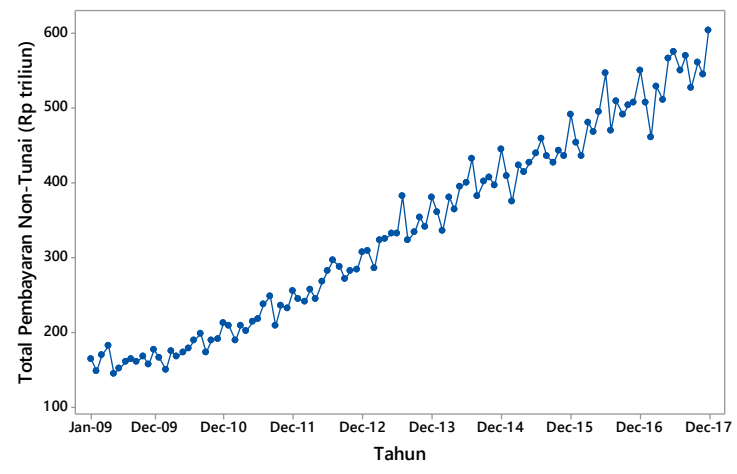

(a)

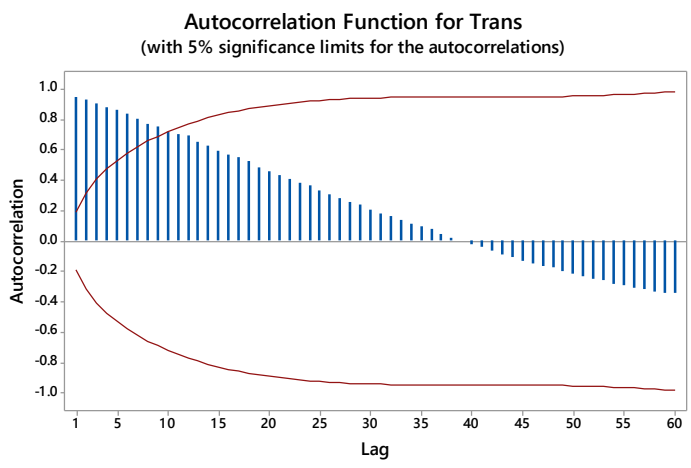

(b)

Gambar 2. Plot Deret Waktu dan ACF Total Pembayaran Non-tunai, 2009-2017

Untuk data yang terindikasi tidak stasioner dalam mean, perlu dilakukan pembedaan (differencing) agar data menjadi stasioner. Pembedaan dilakukan secara reguler dengan orde $d$ sebesar 1 .

Melalui penelusuran ACF dan PACF, terdapat 3 model ARIMA yang diindikasikan representatif, yaitu $\operatorname{ARIMA}(0,1,1)(1,0,0)^{12}, \quad \operatorname{ARIMA}(0,1,2)(1,0,0)^{12}, \quad$ dan $\operatorname{ARIMA}(1,1,1)(1,0,0)^{12}$. Tabel 1 menampilkan signifikansi parameter dan nilai AIC dari tiap model yang dibangun dengan data in-sample.

Tabel 1. Signifikansi Parameter ARIMA dengan Musiman

\begin{tabular}{|lllll|}
\hline \multicolumn{1}{|c}{ Model } & \multicolumn{1}{c}{ Parameter } & Koefisien & $\boldsymbol{p}$-value & AIC \\
\hline \multirow{2}{*}{ ARIMA $(0,1,1)(1,0,0)^{12}$} & MA(1) & 0,731 & $<0,0001$ & \multirow{2}{*}{885,046} \\
\cline { 2 - 4 } & AR(1)_musiman & 0,916 & $<0,0001$ & \\
\hline \multirow{2}{*}{ ARIMA $(0,1,2)(1,0,0)^{12}$} & MA(1) & 0,942 & $<0,0001$ & \\
\cline { 2 - 4 } & MA(2) & $-0,263$ & 0,0075 & \multirow{2}{*}{879,627} \\
\cline { 2 - 4 } & AR(1)_musiman & 0,937 & $<0,0001$ & \\
\hline \multirow{3}{*}{ ARIMA $(1,1,1)(1,0,0)^{12}$} & AR(1) & $-0,300$ & 0,016 & \\
\cline { 2 - 4 } & MA(1) & 0,616 & $<0,0001$ & \\
\cline { 2 - 4 } & AR(1)_musiman & 0,932 & $<0,0001$ & \\
\hline
\end{tabular}

Tabel 1 menunjukkan bahwa seluruh parameter pada tiga opsi model ARIMA signifikan pada $\alpha=5 \%$. Artinya, transaksi pembayaran non-tunai terbukti secara statistik dipengaruhi pula oleh transaksi pada bulan sebelumnya serta galat bulan sebelumnya. Model yang lebih sederhana dan tepat berdasarkan AIC adalah $\operatorname{ARIMA}(0,1,2)(1,0,0)^{12}$. Persamaan (9) adalah model ARIMA $(0,1,2)(1,0,0)^{12}$ berdasarkan data training.

$$
y_{t}=y_{t-1}+0,937 y_{t-12}-0,937 y_{t-13}+\varepsilon_{t}+0,942 \varepsilon_{t-1}-0,263 \varepsilon_{t-2}
$$

\subsection{Pemodelan Pembayaran Non-Tunai dengan ARIMAX}

Dalam penelitian ini, ARIMAX dibangun terlebih dulu melalui regresi deret waktu. Persamaan (10) dan (11) masing-masing merupakan model regresi deret waktu sebagai implementasi dari persamaan (3) dan (4). 
1) Model 1 (tanpa tren deterministik dan musiman)

$$
\begin{aligned}
\hat{y}_{t}= & 332,6+2 D_{t-2}+69,3 D_{t-1}+86,4 D_{t}+6,5 D_{t+1}+51 D_{1, t}-170 D_{2, t}-117 D_{3, t}+ \\
& 145 D_{1, t-1}-112 D_{2, t-1}-102 D_{3, t-1}
\end{aligned}
$$

2) Model 2 (dengan tren deterministik dan musiman)

$$
\begin{aligned}
\hat{y}_{t}= & 4,15 t-2,17 D_{t-2}+12,3 D_{t-1}+26,8 D_{t}-2,97 D_{t+1}-54,7 D_{1, t}-41,6 D_{2, t}- \\
& 16,5 D_{3, t}+49,1 D_{1, t-1}+7,1 D_{2, t-1}-4,7 D_{3, t-1}+111,07 M_{1}+83,98 M_{2}+ \\
& 116,23 M_{3}+104,61 M_{4}+115,09 M_{5}+112,33 M_{6}+120,81 M_{7}+ \\
& 110,1 M_{8}+97,98 M_{9}+109,64 M_{10}+98,92 M_{11}+131,42 M_{12}
\end{aligned}
$$

ARIMAX selanjutnya dibangun dengan menganalisis galat dari model pada persamaan (10) dan (11). Untuk menentukan apakah galat sudah memenuhi syarat stasioneritas dalam mean dan varians, maka diperlukan bantuan ACF yang disajikan pada Gambar 3.

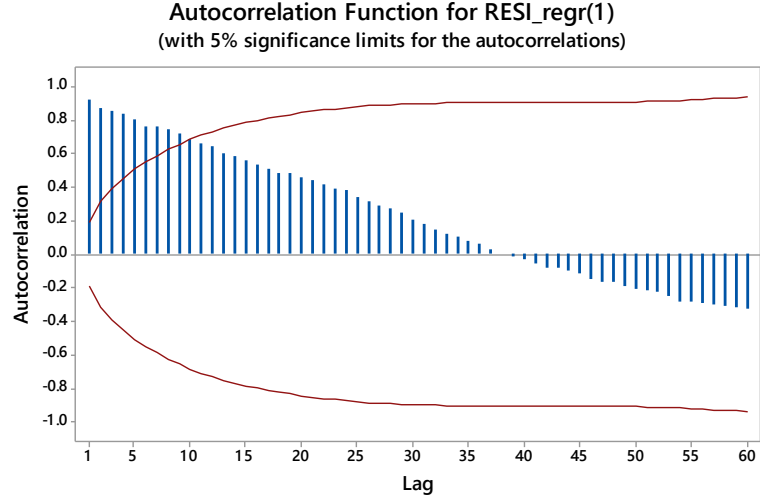

Model 1

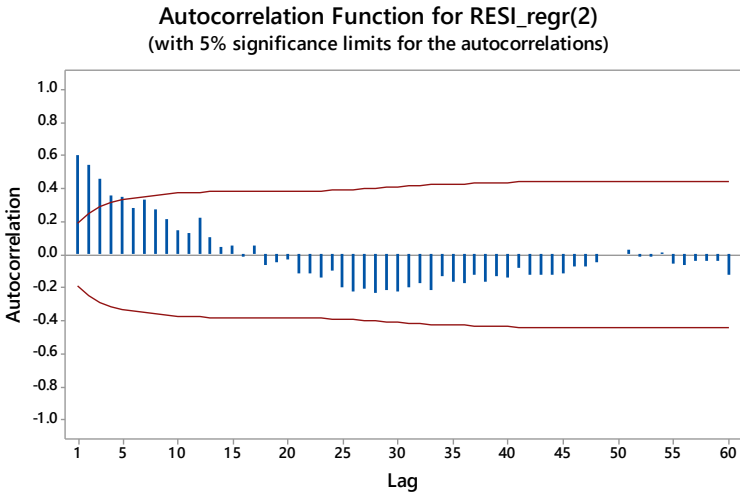

Model 2

Gambar 3. ACF dan PACF Galat Model Regresi Deret Waktu

Gambar 3 mengindikasikan bahwa kedua model tersebut tidak stasioner sehingga perlu dilakukan operasi pembedaan (difference) secara reguler. Untuk menghasilkan ramalan dengan pendekatan ARIMAX, galat dari persamaan (10) dan (11) dimodelkan terlebih dulu dengan ARIMA, lalu ditambahkan dengan estimasi dari model regresi deret waktu. Tabel 2 menyajikan ringkasan RMSE dari data training untuk seluruh alternatif model ARIMAX.

Tabel 2. RMSE Model ARIMAX Data Training

\begin{tabular}{|lcccc|}
\hline $\begin{array}{c}\text { Model Regresi } \\
\text { Deret Waktu }\end{array}$ & Alternatif & RMSE & Alternatif & RMSE \\
\hline \multirow{2}{*}{ Model 1 } & $\operatorname{ARIMAX}(0,1,1)$ & 36,01 & $\operatorname{ARIMAX}(2,1,0)$ & 34,90 \\
& $\operatorname{ARIMAX}(0,1,2)$ & 34,47 & $\operatorname{ARIMAX}(2,1,1)$ & 34,77 \\
\hline \multirow{3}{*}{ Model 2 } & $\operatorname{ARIMAX}(0,1,1)$ & 11,03 & $\operatorname{ARIMAX}(2,1,1)$ & 11,21 \\
& $\operatorname{ARIMAX}(1,1,0)$ & 11,43 & $\operatorname{ARIMAX}(1,1,2)$ & $10,99^{*}$ \\
& $\operatorname{ARIMAX}(2,1,0)$ & 11,13 & & \\
\hline
\end{tabular}

Ket. * model training dengan RMSE terendah

Dari Tabel 2, model training yang memiliki akurasi terbaik untuk model 1 adalah $\operatorname{ARIMAX}(0,1,2)$, sementara model training terbaik untuk model 2 adalah ARIMAX $(1,1,2)$. Berikut ini persamaan ARIMAX dengan akurasi terbaik dari tiap model training.

- Model 1 (ARIMAX $(0,1,2)$ )

$$
\begin{aligned}
\hat{y}_{t}= & 332,6+2 D_{t-2}+69,3 D_{t-1}+86,4 D_{t}+6,5 D_{t+1}+51 D_{1, t}-170 D_{2, t}-117 D_{3, t}+ \\
& 145 D_{1, t-1}-112 D_{2, t-1}-102 D_{3, t-1}+\frac{1-0,265 B-0,331 B^{2}}{1-B} \varepsilon_{t}
\end{aligned}
$$


- Model 2 (ARIMAX $(1,1,2)$ )

$$
\begin{aligned}
\hat{y}_{t}= & 4,15 t-2,17 D_{t-2}+12,3 D_{t-1}+26,8 D_{t}-2,97 D_{t+1}-54,7 D_{1, t}-41,6 D_{2, t}- \\
& 16,5 D_{3, t}+49,1 D_{1, t-1}+7,1 D_{2, t-1}-4,7 D_{3, t-1}+111,07 M_{1}+83,98 M_{2}+ \\
& 116,23 M_{3}+104,61 M_{4}+115,09 M_{5}+112,33 M_{6}+120,81 M_{7}+110,1 M_{8}+ \\
& 97,98 M_{9}+109,64 M_{10}+98,92 M_{11}+131,42 M_{12}+\frac{1-0,643 B+0,063 B^{2}}{(1-0,996 B)(1-B)} \varepsilon_{t}
\end{aligned}
$$

Jika diperhatikan dengan seksama, terlihat bahwa ARIMAX model 2 pada persamaan (13) jauh lebih superior daripada ARIMAX model 1 yang tidak mempertimbangkan aspek musiman dan tren deterministik. Dengan adanya pengetahuan ini, pemodelan dengan ARIMAX-ANN selanjutnya diputuskan menggunakan model 2 karena hasil peramalan yang dihasilkan ARIMAX model 2 lebih akurat.

\subsection{Pemodelan Pembayaran Non-Tunai dengan ARIMAX-ANN}

Dalam model ini, input yang digunakan berasal dari residual model ARIMAX, diantaranya dari persamaan (12) dan (13). Menurut [14], penentuan/seleksi input yang akan dimodelkan dengan ANN dapat dilakukan melalui identifikasi PACF. Galat dengan PACF yang signifikan berpotensi untuk dijadikan sebagai input. Selain itu, pada penelitian ini juga ditawarkan pendekatan baru dalam menyeleksi input model ANN dengan regresi stepwise. Dengan menerapkan metode stepwise, maka diharapkan proses seleksi hanya akan memilih galat dengan pengaruh yang signifikan saja terhadap model ANN (tidak mempertimbangkan seluruh lag galat). Sebagai ilustrasi, Gambar 4 menyajikan PACF galat ARIMAX $(2,1,1)$ model 2 dan ARIMAX(1,1,2) model 2.

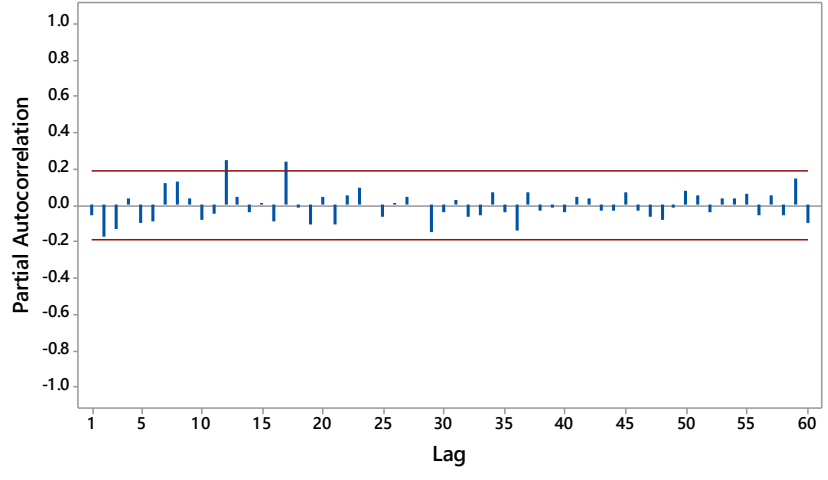

Model 2 ARIMAX $(2,1,1)$

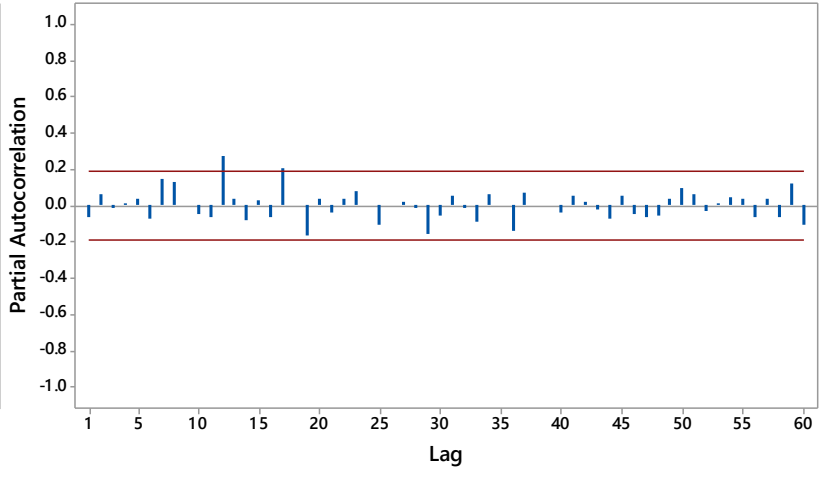

Model 2 ARIMAX $(1,1,2)$

Gambar 4. PACF Galat Model ARIMAX

Gambar 4 mengindikasikan bahwa residual lag-12 dan lag-17 signifikan dimana hal ini tidak diperbolehkan dalam peramalan karena residual pada seluruh lag idealnya tidak signifikan. Jadi, galat lag 12 dan 17 akan menjadi input untuk galat ARIMAX yang dimodelkan dengan ANN untuk skema seleksi PACF. Untuk pemilihan input dengan metode stepwise, residual lag $k$ yang signifikan adalah lag -7, 10, 12 dan 17 untuk ARIMAX (2,1,1) model 2 dan lag -3, 7, 10, 12, 15 dan 17 untuk ARIMAX (1,1,2) model 2.

Dalam penerapan ARIMAX-ANN, dilakukan beberapa percobaan untuk memperoleh hasil yang dianggap terbaik. Tabel 3 meringkas RMSE dari ARIMAX-ANN model 2, khususnya ARIMAX $(2,1,1)$ dan ARIMAX $(1,1,2)$, yang dibangun dari data training yang dijalankan dengan FFNN.

Tabel 3. RMSE Model ARIMAX-ANN untuk Data Training

\begin{tabular}{|lcccc|}
\hline & \multicolumn{2}{c|}{$\operatorname{ARIMAX}(2,1,1)$} & \multicolumn{2}{c|}{ ARIMAX $(1,1,2)$} \\
\cline { 2 - 5 } & PACF & Stepwise & PACF & Stepwise \\
\hline RMSE & 8,93 & 9,24 & 8,51 & 8,09 \\
\hline $\begin{array}{l}\text { Banyak unit pada } \\
\text { hidden layer }\end{array}$ & 2 & 1 & 3 & 3 \\
\hline
\end{tabular}


Dari Tabel 3, dapat dikatakan bahwa ARIMAX-ANN memiliki akurasi yang lebih baik daripada ARIMAX, terutama untuk peramalan data training. Dari dua macam seleksi input, PACF dan stepwise sama-sama unggul dimana PACF menghasilkan keakuratan yang lebih baik pada $\operatorname{ARIMAX}(2,1,1)$ dengan 2 unit hidden layer, sementara stepwise unggul pada ARIMAX $(1,1,2)$ dengan 3 unit hidden layer. Persamaan (14) adalah ilustrasi model ARIMAX $(2,1,1)$ dengan 2 unit hidden layer melalui seleksi input PACF.

$$
\begin{aligned}
\hat{y}_{t}= & 332,6+2 D_{t-2}+69,3 D_{t-1}+86,4 D_{t}+6,5 D_{t+1}+51 D_{1, t}-170 D_{2, t}-117 D_{3, t}+ \\
& 145 D_{1, t-1}-112 D_{2, t-1}-102 D_{3, t-1}+\frac{1-0,85 B}{1-0,95 B-0,38 B^{2}} \varepsilon_{t}+\hat{N}_{t}
\end{aligned}
$$

dimana

$\hat{N}_{t}=\alpha_{0}+\sum_{j=1}^{2} \alpha_{j} g\left(\beta_{0 j}+\sum_{i=1}^{2} \beta_{i j} y_{t-i}\right)$. Diperoleh nilai $\alpha_{0}=-0,04, \alpha_{1}=-0,87, \alpha_{2}=-0,69, \beta_{01}=0,49$,

$\beta_{11}=-0,38, \beta_{21}=-0,79, \beta_{02}=-0,37, \beta_{12}=-0,57, \beta_{22}=0,04$. Untuk fungsi aktivasi pada persamaan (14), menggunakan hyperbolic tangent seperti ditampikan pada persamaan (15)

$$
g\left(y_{t}\right)=\tanh \left(y_{t}\right) .
$$

\subsection{Pemilihan Model Terbaik}

Sebelum memasuki tahap pemilihan model terbaik, dilakukan pemeriksaan asumsi apakah galat hasil ramalan dari model ARIMA, ARIMAX dan ARIMAX-ANN memenuhi asumsi identik, independen, dan berdistribusi normal (IIDN). Hal ini untuk memastikan bahwa model telah memadai sebagai model peramalan

\begin{tabular}{|c|c|c|c|c|}
\hline & Alternatif model & Asumsi white noise & Asumsi independen & Asumsi normalitas \\
\hline \multirow{3}{*}{ ARIMA } & $\operatorname{ARIMA}(0,1,1)(1,0,0)^{12}$ & Memenuhi & Memenuhi & Memenuhi \\
\hline & $\operatorname{ARIMA}(0,1,2)(1,0,0)^{12}$ & Memenuhi & Memenuhi & Memenuhi \\
\hline & $\operatorname{ARIMA}(1,1,1)(1,0,0)^{12}$ & Memenuhi & Memenuhi & Memenuhi \\
\hline \multirow{5}{*}{$\begin{array}{l}\text { ARIMAX } \\
\text { Model } 2\end{array}$} & $\operatorname{ARIMAX}(0,1,1)$ & Memenuhi & Memenuhi & Memenuhi \\
\hline & ARIMAX $(1,1,0)$ & Memenuhi & Memenuhi & Memenuhi \\
\hline & ARIMAX $(2,1,0)$ & Memenuhi & Memenuhi & Tidak memenuhi \\
\hline & $\operatorname{ARIMAX}(2,1,1)$ & Memenuhi & Memenuhi & Memenuhi \\
\hline & ARIMAX $(1,1,2)$ & Memenuhi & Memenuhi & Memenuhi \\
\hline \multirow{4}{*}{$\begin{array}{l}\text { ARIMAX- } \\
\text { ANN } \\
\text { Model } 2\end{array}$} & $\begin{array}{l}\text { ARIMAX }(2,1,1) \text { dengan } \\
2 \text { hidden layer, seleksi } \\
\text { input PACF }\end{array}$ & Memenuhi & Memenuhi & Memenuhi \\
\hline & $\begin{array}{l}\text { ARIMAX }(2,1,1) \text { dengan } \\
1 \text { hidden layer, seleksi } \\
\text { input stepwise }\end{array}$ & Memenuhi & Memenuhi & Memenuhi \\
\hline & $\begin{array}{l}\text { ARIMAX }(1,1,2) \text { dengan } \\
3 \text { hidden layer, seleksi } \\
\text { input PACF }\end{array}$ & Memenuhi & Memenuhi & Memenuhi \\
\hline & $\begin{array}{l}\text { ARIMAX }(1,1,2) \text { dengan } \\
3 \text { hidden layer, seleksi } \\
\text { input stepwise }\end{array}$ & Memenuhi & Memenuhi & Memenuhi \\
\hline
\end{tabular}
pembayaran non-tunai. Hasil pemeriksaan asumsi disajikan secara ringkas dalam Tabel 4.

Tabel 4. Pemenuhan Asumsi IIDN

Tabel 4 menunjukkan bahwa sebagian besar alternatif model memenuhi asumsi IIDN. Kemudian, memilih model terbaik dengan acuan nilai RMSE terendah. Indikator ini digunakan karena model dengan RMSE terendah mengindikasikan kemampuan model yang akan menghasilkan ramalan dengan kesalahan (galat) yang lebih rendah. Tabel 5 menampilkan RMSE dari seluruh alternatif model yang dimungkinkan. 
Tabel 5. Perbandingan RMSE Model Training dan Testing

\begin{tabular}{|c|c|c|c|}
\hline & \multirow{2}{*}{ Alternatif Model } & \multicolumn{2}{|c|}{ RMSE } \\
\hline & & Training & Testing \\
\hline \multirow{3}{*}{ ARIMA } & $\operatorname{ARIMA}(0,1,1)(1,0,0)^{12}$ & 14,85 & 43,66 \\
\hline & $\operatorname{ARIMA}(0,1,2)(1,0,0)^{12}$ & 14,35 & 44,54 \\
\hline & $\operatorname{ARIMA}(1,1,1)(1,0,0)^{12}$ & 14,42 & 44,20 \\
\hline \multirow{5}{*}{$\begin{array}{l}\text { ARIMAX } \\
\text { Model } 2\end{array}$} & $\operatorname{ARIMAX}(0,1,1)$ & 11,03 & 26,55 \\
\hline & $\operatorname{ARIMAX}(1,1,0)$ & 11,43 & 25,17 \\
\hline & $\operatorname{ARIMAX}(2,1,0)$ & 11,13 & 25,58 \\
\hline & $\operatorname{ARIMAX}(2,1,1)$ & 11,21 & 24,63 \\
\hline & $\operatorname{ARIMAX}(1,1,2)$ & 10,99 & 26,50 \\
\hline \multirow{4}{*}{$\begin{array}{l}\text { ARIMAX-ANN } \\
\text { Model } 2\end{array}$} & $\begin{array}{l}\text { ARIMAX }(2,1,1) \text { dengan } 2 \text { hidden } \\
\text { layer, seleksi input PACF }\end{array}$ & 8,93 & 21,97 \\
\hline & $\begin{array}{l}\text { ARIMAX }(2,1,1) \text { dengan } 1 \text { hidden } \\
\text { layer, seleksi input stepwise }\end{array}$ & 9,24 & $20,90^{*}$ \\
\hline & $\begin{array}{l}\text { ARIMAX }(1,1,2) \text { dengan } 3 \text { hidden } \\
\text { layer, seleksi input PACF }\end{array}$ & 8,51 & 21,68 \\
\hline & $\begin{array}{l}\text { ARIMAX }(1,1,2) \text { dengan } 3 \text { hidden } \\
\text { layer, seleksi input stepwise }\end{array}$ & $8,10^{*}$ & 21,25 \\
\hline
\end{tabular}

* Model dengan RMSE terendah

Dari Tabel 5 diindikasikan bahwa ARIMAX-ANN menghasilkan ramalan pembayaran non-tunai, baik untuk data training dan data testing, yang jauh lebih akurat daripada ARIMA dan ARIMAX. Atas hasil ini, diindikasikan pula bahwa adanya model hybrid yang mengkombinasikan ARIMAX untuk mengidentifikasi efek kalender dan ANN untuk meningkatkan akurasi mampu menghasilkan ramalan pembayaran non-tunai yang mendekati nilai aktual. Gambar 5 menampilkan peramalan pembayaran non-tunai untuk ARIMAX dan ARIMAX-ANN data testing dengan RMSE masing-masing sebesar Rp 24,63 triliun dan Rp 20,9 triliun.

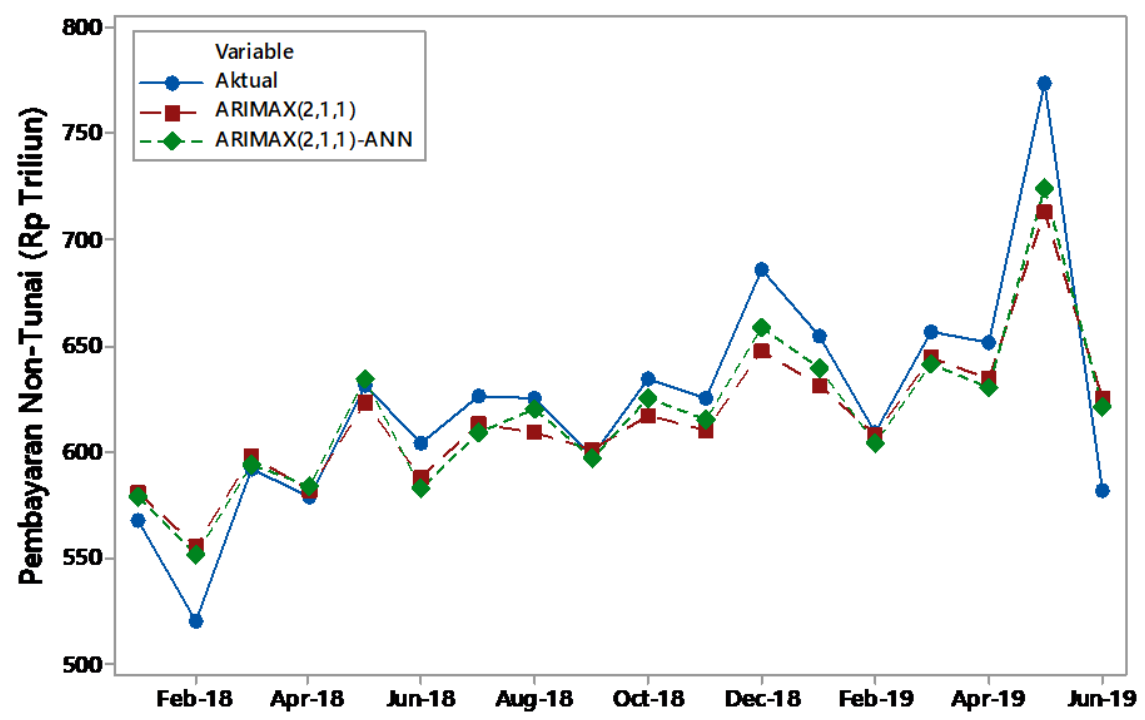

Gambar 5. Plot Peramalan Pembayaran Non-tunai untuk Data Testing

Dari Gambar 5, model hybrid ARIMAX(2,1,1)-ANN terbukti paling akurat dari seluruh opsi model peramalan total pembayaran non-tunai karena selalu tepat dalam mengikuti dinamika data. Pada bulan-bulan tertentu, ramalan yang dihasilkan hybrid ARIMAX-ANN sangat akurat karena selisih antara nilai aktual dan nilai ramalan mendekati 0 . Selain itu, model ARIMAX $(2,1,1)$-ANN juga mampu untuk meramalkan pembayaran non-tunai pada periode yang bertepatan dengan bulan terjadinya Idul Fitri maupun akhir tahun. 


\section{KESIMPULAN}

Model hybrid ARIMAX-ANN digunakan untuk meramalkan pembayaran non-tunai yang saat ini sedang menjadi skema pembayaran paling menarik. Untuk memperoleh model ANN terbaik, maka metode seleksi input yang digunakan adalah dua, yaitu dengan regresi stepwise dan signifikansi PACF galat model ARIMAX. Metode ARIMAX-ANN merupakan model terbaik untuk peramalan pembayaran non-tunai dengan RMSE terendah, yaitu Rp 20,9 triliun. Spesifikasi model terbaik tersebut adalah ARIMAX $(2,1,1)$ yang dihibrida dengan ANN 2 unit (node) pada hidden layer atas input hasil regresi stepwise terhadap galat ARIMAX. Model ini juga memenuhi asumsi IIDN yang disyaratkan. Beberapa hal yang perlu dikembangkan untuk penelitian selanjutnya adalah model hybrid dengan pendekatan non-linier lainnya, yaitu dengan menggunakan machine learning ANFIS, SVM, dan sebagainya. Model utama selain ARIMA juga menjadi opsi yang layak dikembangkan, seperti regresi robust untuk mengantisipasi pencilan. Model regresi robust merupakan improvisasi dari model regresi regular dengan memberikan bobot kepada titik-titik pengamatan yang diduga sangat mempengaruhi hasil estimasi. Dengan regresi robust, data yang menunjukkan nilai rendah dan tinggi secara tidak lazim diharapkan dapat tertangani.

\section{DAFTAR PUSTAKA}

[1] A. Suharsono, Suhartono, A. Masyitha and A. Anuravega, "Time Series Regression and ARIMAX for Forecasting Currency Flow at Bank Indonesia in Sulawesi Region," in AIP Conference Proceedings, 1691, id. 050025, pp. 1$8,2015$.

[2] Bank Indonesia, Kajian Stabilitas Keuangan No. 31, Jakarta : Bank Indonesia, September 2018.

[3] D. A. Tribudhi and S. Soekapdjo, "Determinasi transaksi dengan menggunakan uang elektronik di Indonesia," Kinerja, vol. 16, no. 1, pp. 78-84, 2019.

[4] D.D. Prastyo, Suhartono, A.O.B. Puka and M.H. Lee, "Comparison Between Hybrid Quantile Regression Neural Network and Autoregressive Integrated Moving Average with Exogenous Variable for Forecasting of Currency Inflow and Outflow in Bank Indonesia," Jurnal Teknologi, vol. 80, no. 6, pp. 61-68, 2018.

[5] F.F. Amalia, Suhartono, S.P. Rahayu and N. Suhermi, "Quantile Regression Neural Network for Forecasting Inflow and Outflow in Yogyakarta," Journal of Physics: Conference Series, 1028, id. 012232, pp. 1-10, 2018.

[6] G.E.P. Box, G.M. Jenkins and G.C. Reinsel, Time Series Analysis, Forecasting and Control, $4^{\text {th }}$ edition, New Jersey: John Wiley \& Sons Inc, 2008

[7] G.P. Zhang and M. Qi, "Neural network forecasting for seasonal and trend time series," European Journal of Operational Research, vol. 160, no. 2, pp. 501-514, 2005.

[8] H. Febrianty, "Pengaruh Sistem Pembayaran Non-tunai dalam Era Digital terhadap Tingkat Pertumbuhan Ekonomi Indonesia," in Prosiding Festival Riset Ilmiah Manajemen dan Akuntansi, pp. 306-314, Feb. 24, 2019.

[9] I.G.S.A. Prayoga, Suhartono and S.P. Rahayu, "Forecasting currency circulation data by using hybrid ARIMAXANN model," in AIP Conference Proceedings, 1842, id. 030029, 2017.

[10] M. Kumar and M. Thenmozhi, "Forecasting stock index returns using ARIMA-SVM, ARIMA-ANN, and ARIMArandom forest hybrid models," Int. J. Banking, Accounting and Finance, vol. 5, no. 3, pp. 284-308, 2014.

[11] R.M.K.T. Ratnayaka, D.M.K.N. Seviratne, W. Jianguo and H.I. Arumawadu, "A Hybrid Statistical Approach for Stock Market Forecasting Based on Artificial Neural Network and ARIMA Time Series Models," presented at 2015 International Conference on Behavioral, Economic, and Socio-Cultural Computing, Nanjing, China, 2015.

[12] Setiawan, Suhartono, I.S. Ahmad and N.I. Rahmawati, "Configuring calendar variation based on time series regression method for forecasting of monthly currency inflow and outflow in Central Java," in AIP Conference Proceedings, 1691, id. 050024, pp. 1-8, 2015.

[13] Suhartono, M.H. Lee and N.A. Hamzah, "Calendar Variation Model Based on ARIMAX for Forecasting Sales Data with Ramadhan Effect," in Proceedings of the Regional Conference on Statistical Sciences (RCSS), pp. 3041, 2010.

[14] Suhartono, P.D. Saputri, F.F. Amalia, D.D. Prastyo dan B.S.S. Ulama, "Model Selection in Feedforward Neural Networks for Forecasting Inflow and Outflow in Indonesia," in A. Mohamed, M. Berry, B. Yap (eds) Soft Computing in Data Science, SCDS 2017 Communications in Computer and Information Science, vol. 788, pp. 95$105,2017$.

[15] Suhartono, S.P. Rahayu, D.D. Prastyo, D.G.P. Wijayanti and Juliyanto, "Hybrid model for forecasting time series with trend, seasonal and salendar variation patterns," Journal of Physics: Conference Series, 890, id. 012160, pp. $1-7,2017$.

[16] U.S. Mujtaba, "Ramadan: the month of fasting for Muslims, and tourism studies-Mapping the unexplored connection,” Tourism Management Perspectives, vol. 19, part B, pp. 170-177, 2016.

[17] W. Alam, M. Ray, R.R. Kumar, K. Sinha, S. Rathod and K.N. Singh, "Improved ARIMAX model based on SVM and ANN approaches for forecasting rice yield using weather variables," Indian Journal of Agricultural Science, vol. 88, no. 12, pp. 1909-1913, 2018. 
[18] W. Anggraeni, R. A. Vinarti and Y. D. Kurniawati, "Performance Comparisons between ARIMA and ARIMAX Method in Moslem Kids Clothes Demand Forecasting: Case Study," in Procedia Computer Science, vol. 72, pp. 630-637, 2015. 